\title{
DISTRIBUTION AND INVASION OF CLEARWING MOTH Synanthedon tipuliformis Cl., A PEST OF CURRANT, IN LATVIA
}

\author{
Laura Ozolina-Pole, Ilze Apenīte, and Rinalds Ciematnieks \\ Latvian Plant Protection Research Centre, Ltd., Struktoru 14a, Rīga LV-1039, LATVIA \\ laura.ozolina.pole@laapc.Iv
}

Communicated by Arvīds Barševskis

\begin{abstract}
The aim of the present study was to determine the distribution and prevalence of $\mathrm{S}$. tipuliformis in Latvia. In 2008-2009, trials were carried out in blackcurrant plantations aimed at establishing the distribution of S. tipuliformis across the territory of Latvia. To achieve this goal, 13 blackcurrant plantations were surveyed in 2008. The research was continued in three plantations in 2009. To assess of prevalence and level of damage caused by the S. tipuliformis, two methods were used: cutting of branches (five branches were cut from each bush) and pheromone traps with dispensers (distributed in each trial farm with density one trap per ha). The presence of $\mathrm{S}$. tipuliformis was recorded in all 13 horticultural farms surveyed in 2008. Analyses of the branch samples demonstrated that the pest invaded from 3\% to $70 \%$ of the branches. A total of 2.5 to 35 adults were caught per pheromone trap. The highest proportion of the branches invaded by the $\mathrm{S}$. tipuliformis was in 2008 (70\%) and the highest number of males in traps in 2009 was recorded in Jelgava municipality. S. tipuliformis is widely found in blackcurrant growing plantations across the whole territory of Latvia.
\end{abstract}

Key words: currant clearwing moth, distribution, damage in Latvia.

The currant clearwing moth Sinanthedon tipuliformis Clerk. (Synonym Spinx tipula) (Lepidoptera: Sesiidae) is a cosmopolitan pest species found all over the world where black currants are grown and it is one of the most important pests for plants of the genus Ribes (Brock et al., 1964; Manko, 1965; Leska, 1966; Yakimova, 1968; Scott and Harrison, 1978; Hardy, 1981; Būda, 1993; Gottwald \& Künzel, 1994) S. tipuliformis is a major pest in black currant plantations of Lithuania (Būda, 1993). In Latvia it has been little investigated and the distribution and density of its population is unknown here.

S. tipuliformis develops one generation per year. Females fly and oviposit their eggs from the beginning of June to the end of July. The eggs are laid singly on the bark of the black currant canes near buds. The hatched larvae chew their way inside the cane and feed on the medulla part of the black currant shoots. Before pupation, it gnaws a passage out of the trunk. The shoot then dies because of the damage. The damaged spots may be attacked by various fungal diseases (Manko, 1965; Hardy, 1981).

Due to the secluded lifecycle of S. tipuliformis, chemical treatment for pest control is hardly possible and the estimation of the population density in a farm is very complicated.

Traditionally, the population density of clearwing moth in a black currant field is estimated by branch analysis. Phero- mone traps are more often used for determination of the beginning of flying and dynamics during the vegetation period. This application however is insufficient for monitoring of density (Subchev et al., 1993; Gottvald \& Künzel, 1994; James et al., 2001). Therefore, the two aforementioned methods were both used.

The aim of the study was to determine the distribution and invasion of S. tipuliformis in Latvia in 2008-2009.

The monitoring was carried out over the vegetation period in black currant (Ribes nigrum L.) plantations in different places of Latvia in 2008-2009. In 2008, the survey was performed in 13 private holdings scattered over different municipalities of Latvia: Dobele, Ikškile (2), and Jelgava. The survey was continued in municipalities of Tukums (western part of Latvia), Jelgava (central part of Latvia), and Pārgauja (central-eastern part of Latvia) municipalities in 2009.

Two methods were used for establishment of damage level caused by $S$. tipuliformis:

(1) agrotechnical method - cutting of branches and seeking for larvae. Black currant bushes were randomly selected from the black currant field. Six bushes were selected and from each five branches were cut, i.e. altogether 30 branches from each field. The branches were cut at the root. 
Samples were taken twice per vegetation period: in spring and in the autumn.

In the laboratory, the collected branches were cut in shorter pieces, marking shoots damaged by $S$. tipuliformis in previous years (no larvae) and branches with $S$. tipuliformis larvae inside;

(2) biological method - pheromone traps. At the beginning of the flying period of S. tipuliformis (mid-May), pheromone traps (PHEROBANK) with dispensers EZ-2, 13-18:Ac were placed in each plantation - one trap per ha according to Сорока, 2005. The traps were hung in the upper part of black currant bushes, i.e. the most efficient location for pheromone trapping (Buda, Karalius, Mozūtaitis 2003). Recording was made once a week, changing the sticky liners each time. Following the recommendations of PHEROBANK (www.pherobank.nl) the dispensers were changed every four weeks after placement in the field.

The recorded data in plantations surveyed in Latvia (13 in total) over the vegetation period of 2008 demonstrated the presence of $S$. tipuliformis in the whole territory of Latvia. In the 1980s, however, abundant populations of S. tipuliformis were observed only around Rīga (Priedītis, 1996). Mass breeding of this pest can cause extensive damage to currant plantations over the whole country.

The branch analysis established the presence of one $S$. tipuliformis larvae on average for every invaded branch. The highest proportion of damaged shoots was found in municipalities of Pārgauja and Viesìte where in spring up to $96.7 \%$ of shoots were damaged (Fig. 1) in 2008. The high number of the damaged shoots may be explained by failure of the black currant growers to ensure appropriate agro technical measures: the damaged shoots have not been timely removed. In spring of 2008 , the proportion of damaged shoots ranged from 3 to $96.7 \%$ while in autumn it decreased from 3.3 to $56.7 \%$.

The proportion of invaded shoots with S. tipuliformis in spring of 2008 was from 3 to $70 \%$, in autumn $-3-56 \%$. In autumn, in municipalities of Tukums, Jelgava, Ikšķile 2, Ikšķile, Dobele, Saldus 2, Pārgauja and Lubāna, the invasion level declined, while in municipalities of Tukums 2, Talsi, Viesīte and Kekava it had increased. These black currant plantations are situated close to residential areas where people grow black currants in small private gardens. In Saldus municipality, the number of damaged shoots both in spring and autumn monitoring was $23 \%$ (Fig. 2.).

Since the monitoring in 2008 confirmed the presence of $S$. tipuliformis in all studied black currant plantations, further survey in 2009 was continued only in three locations, in western, central and central-eastern Latvia (Fig. 3.).

In the vegetation season of 2008, on average 10-20 S. tipuliformis males per trap per season were caught in the studied 13 plantations. In 2009, the number of males caught was 32-35 males per trap per season.

The proportion of branches with larvae was lower in Tukums municipality (western Latvia), both in the vegetation season of 2008 and spring of 2009. Recording of larvae in the branches in the fall of 2009 showed an increase of number larvae-infested branches by $14 \%$ (Fig. 4.). In Jelgava municipality (central Latvia) the poportion of infested branches declined from $70 \%$ (in spring of 2008) to $10 \%$ (in the autumn of 2009). In Pārgauja municipality (central-eastern Latvia), proportion of branches with $S$. tipiliformis larvae declined from 57\% (spring of 2008) to $7 \%$ (autumn of 2009). The proportion of invaded shoots was 3\%, while at the time of formation of new generation it was estimated to be approximately $7 \%$ in spring of 2009 . A large number of $S$. tipuliformis was captured by pheromone traps in the central-eastern part of Latvia (28 S. tipuliformis individuals on the average over the flying period) in 2008, and increased to 32 individuals in vegetation period of 2009 (Fig. 5).

The first survey in black currant plantations in Latvia, carried out in 1980, described a large S. tipuliformis population only in Rīga municipality (Priedītis, 1996). The surveys carried out in 2008 and 2009 showed that $S$. tipuliformis popu-

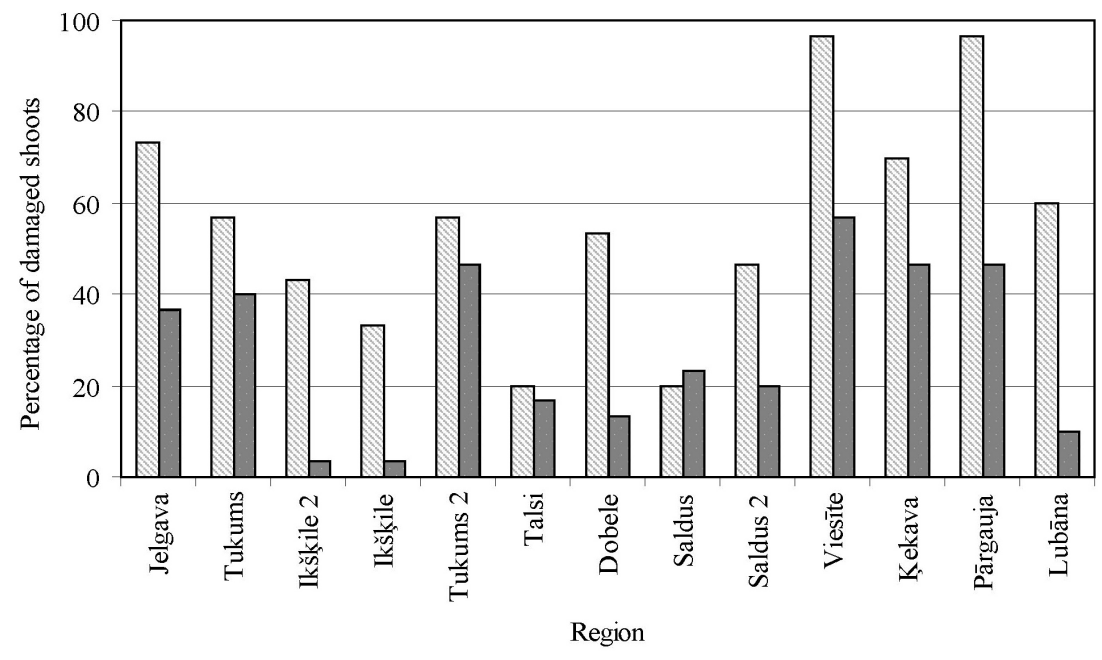

$\square$ Spring $\square$ Autumn
Fig. 1. Proportion (\%) of damaged shoots in 2008. 


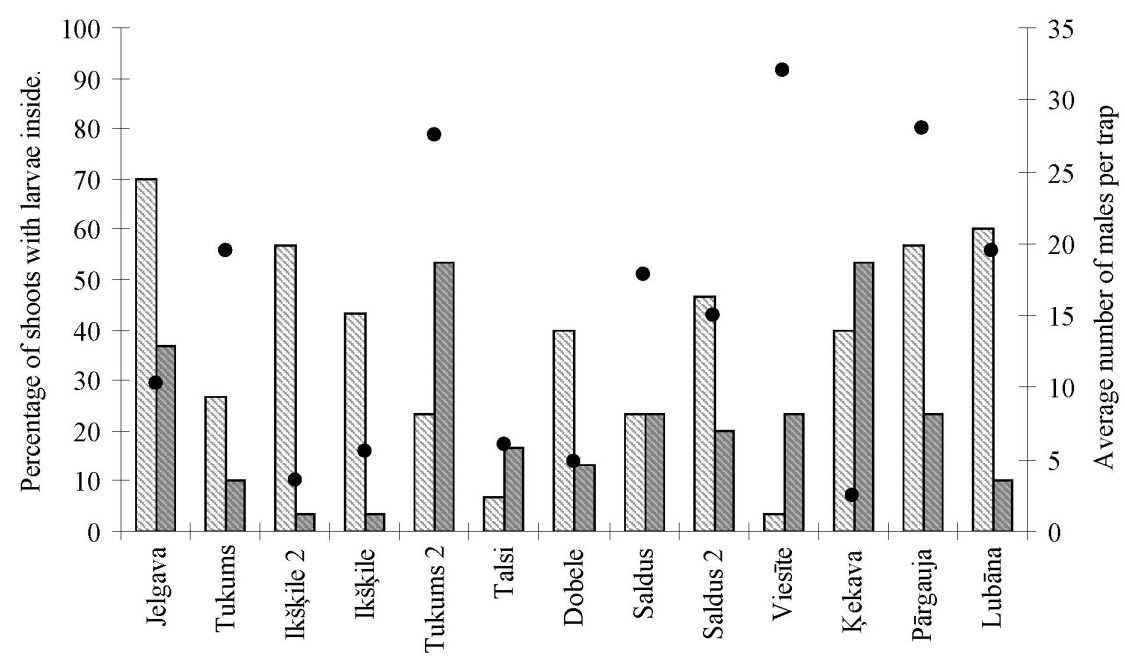

@ Spring $\square$ Autumn $\bullet$ Average number of males per flight season

Fig. 2. Proportion of black currant shoots with Synanthedon tipuliformis larvae and average flight activity of males per season in each plantation.

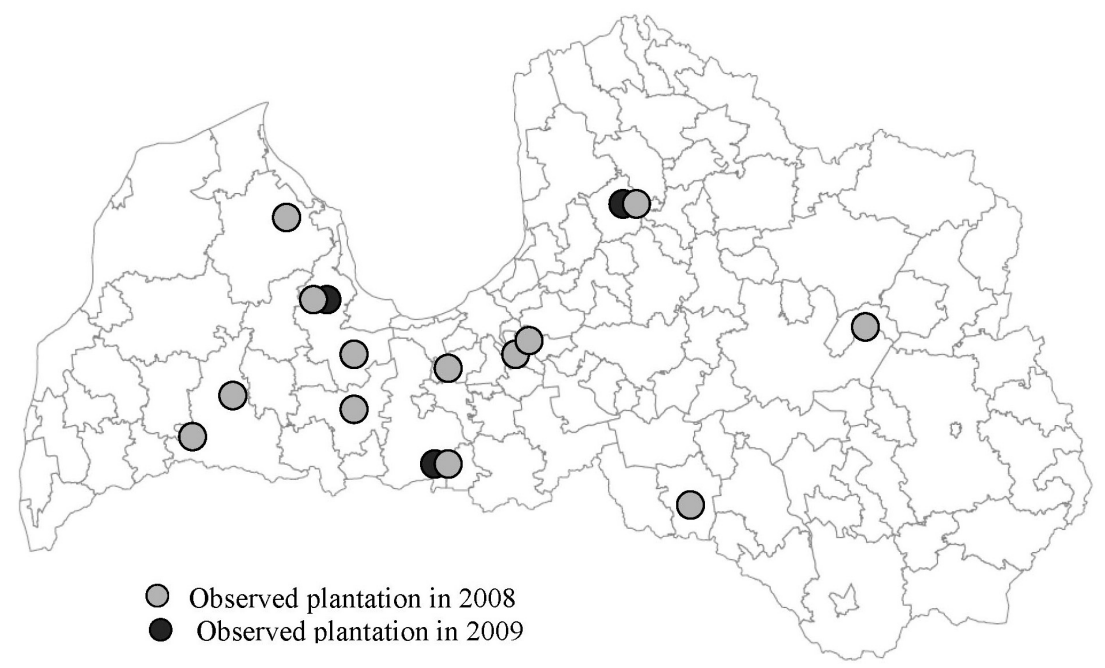

Fig. 3. Schematic map with sites of the observed black currant plantations

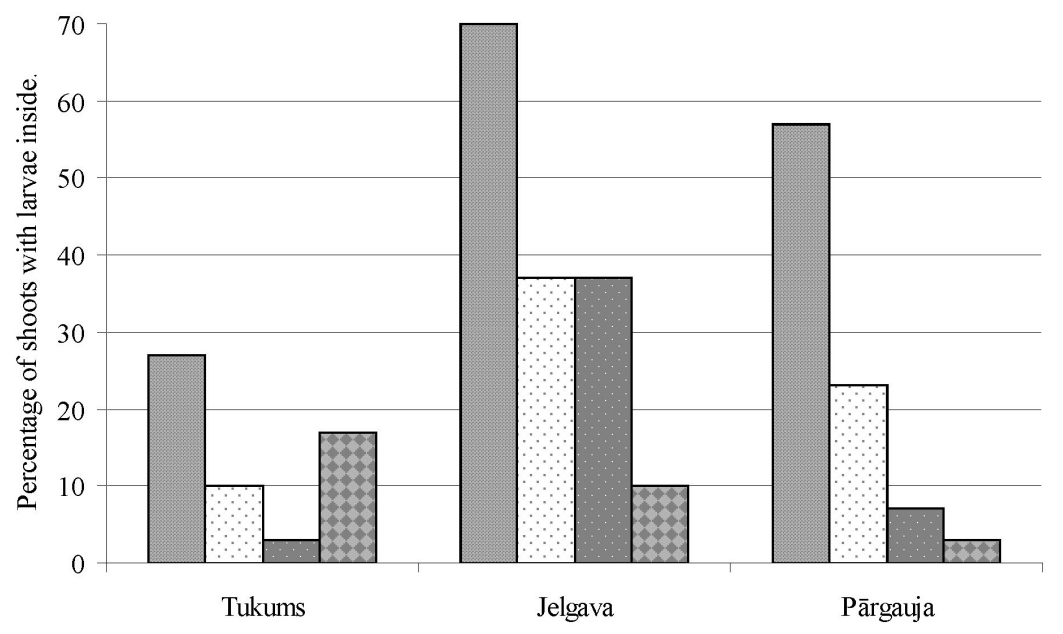

$\square$ Spring, $2008 \square$ Autumn, $2008 \square$ Spring, $2009 \square$ Autumn, 2009

Fig. 4. Proportion of black currant shoots with $S$. tipuliformis larvae in 2008 and 2009.

lation was spread over the whole territory of Latvia. The invasion level of currant shoots invaded by S. tipuliformis in Lithuania was recorded as $1.4-9.2 \%$ in 1989, while in 1990 it was $1.2-68.8 \%$. The monitoring was carried out for a second year in seven holdings, and after application of the pheromone traps, the number of invaded shoots was re- duced 1.77 times. The invasion level was reduced only in one holding (Karalius et al., 2003). Investigations in Latvia showed that in Tukums (Western part of Latvia), Jelgava (Central part of Latvia) and Pārgauja (Central-Eastern part of Latvia) municipalities the invasion level in spring of 2008 was $24-50 \%$ higher than in the same period in 2009. 


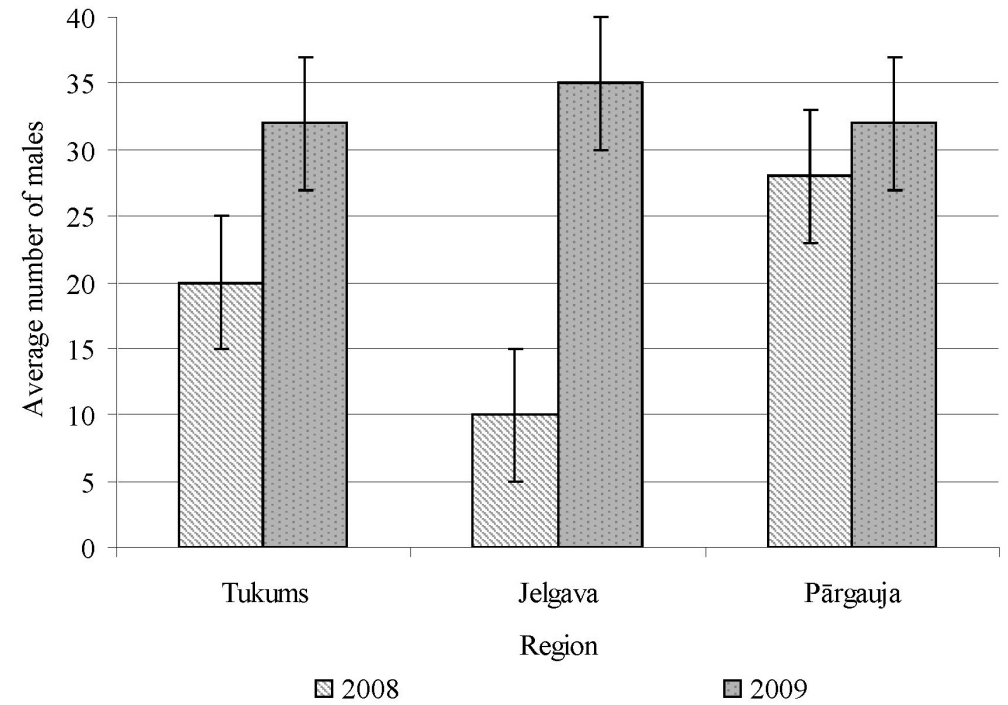

Fig. 5. Average number of S. tipuliformis males per trap in 2008 and 2009.
The current research indicated S. tipuliformis as the most important pest of black currant in Latvia. Population control of S. tipuliformis in Latvia is required, by both cutting of invaded branches and use of pheromone traps.

\section{ACKNOWLEDGEMENTS}

This study was performed with financial support of the Ministry of Agriculture in the project "Specification of environment friendly technologies in fruit and berry plantations in different soil, and climatic conditions".

\section{REFERENCES}

Brock, A. M., Collingwood, C. A., White, J. M. (1964). The currant clearwing moth Aegeria tipuliformis (Cl.) as a pest of blackcurrants. Ann. Appl. Biol., 53 (3), 243-249.

Karalius, V., Būda, V., Mozūraitis, R. (2003). Monitoring f the currant clearwing (Synanthedon tipuliformis $\mathrm{Cl}$.) (Lepidoptera, Sesiidae) by pheromone traps in Lithuanica. Acta Zool. Lituan., 13 (3) 283-289.

Gottwald, R., Künzel, K. (1994). Neue Erkenntnisse zur Populationsökologie des Johannisbeerglasflüglers (Synanthedon tipuliformis Clerck). Gesunde Pflanz., 46, 131-136.
Hardy, R. J. (1981). Field observations on the effect of currant borer moth, Synanthedon tipuliformis (Clerck) (Lepidoptera: Aegeriidae), on the yield of blackcurrants produced in Tasmania. Sci. Hort., 15, 165-172.

James, D. G., Cosse, A., Wright, L. C., Perez, J. (2001). Pheromone traping of Synanthedon tipuliformis (Lepidoptera: Sesiidae) in Washigton red currants. Environ. Entomol., 30 (4), 663-666.

Leska, W. (1966). Studies on the biology of currant clearwing (Synanthedon tipuliformis Cl.) (Lep. Aegeriidae, syn. Sesiidae). Polskie Pismo Entomologiezne B 3-4 (19), 245-261.

Manko, V. V. (1965). On biology of currant clearwing moth under Byelorussian conditions. Newslett. Acad. Sci. Belarus SSR. Ser. Agr. Studies, 4, 70-76 (in Belarusian).

Priedītis, A. (1996). Kultūraugu kaitēkḷi [Cultivated Plant Pests]. Rīga: Zvaigzne ABC. 293 lpp. (in Latvian).

Scott, R. R., Harrison, R. A. (1978). Sampling plan for population dynamics studies on currant clearwing, Synanthedon tipuliformis (Lepidoptera: Sesiidae). New Zealand J. Zool., 5 (1), 177-184.

Subcev, M., Tzolova, E., Szöcs, G., Toth, M. (1993). Monitoring the currant borer, Synanthedon tipuliformis $\mathrm{Cl}$. (Lepidoptera, Sesiidae) by pheromone traps in Bulgaria. Acta Phytopathol. Entomol. Hungarica, 28 (2-4), 435-440.

Yakimova, N. L. (1968). Some factors influencing the population Dynamics of Synanthedon tipuliformis Cl. (Lepidoptera, Aegeriidae). Entomol. Rev., 47 (1), 19-30.

Сороки С. В. (2005). Интегрированнные системы защиты сельскохозайственных культур от вредителей болезней сорняков [Integrated protection of crops from pests, diseases, and weeds]. Минск: Беларуская наука. 461 с. (in Russian).

Received 3 April 2013

\section{JĀṆOGU STIKLSPĀRN̦A (Synanthedon tipuliformis Cl.) IZPLATĪBAS UN UPEN̦U BOJĀJUMU PAKĀPES NOTEIKŠANA LATVIJAS TERITORIJĀ}

Pētījuma mērḳis bija noteikt jāṇogu stiklspārṇa izplatību un upeṇu bojājumus Latvijas teritorijā. Lai noteiktu jāṇogu stiklspārṇa populācijas izplatību, 2008.-2009. gados tika veikti pētījumi upeņu stādījumos. 2008. gadā tika apsekotas 13 saimniecības (Dobeles, Ikšķiles, Jelgavas, Kekavas, Lubānas, Pārgaujas, Saldus, Talsu, Tukuma un Viesītes novados), kurās ir upeṇu stādījumi. 2009. gadā pētījums tika turpināts Jelgavas, Pārgaujas un Tukuma novados. Stiklspārņa konstatēšanai un bojājuma pakāpes noteikšanai tika izmantotas divas metodes: zaru griešana un kāpuru meklēšana. Upeņu laukā randomizēti tika izvēelêti upeņu krūmi. No katra no sešiem krūmiem tika izgriezti pieci zari, kopā 30 zari no katra lauka. Katrā saimniecībā tika izlikti feromonu (PHEROBANK) ḳeramslazdi ar dispenseriem — viens slazds uz vienu hektāru upeņu stādījumu. 2008. un 2009. gadā jāṇogu stiklspārnis tika konstatêts visās 13 apsekotajās saimniecībās. Zaru analīzes rezultāti parādīja, ka invadēti tiek 3-70\% no analizētajiem zariem. Feromonu ķeramslazdos tika uzskaitīti 2.5-35 pieaugušie indivīdi. Lielākais invadēto zaru īpatsvars 2008. gadā (70\%) kā arī tēviṇu daudzums feromonu ḳeramslazdos 2009. gadā (35 indivīdu slazdā) bija Jelgavas novadā. Jāṇogu stiklspārṇa populācija ir izplatīta visā Latvijas teritorijā. 